\title{
Charles C. Cumberland (1914-1970)
}

THE DEATH OF Charles C. Cumberland on March 25, 1970, deprived the academic world of a distinguished Latin Americanist. He died in harness in Lima, Peru, on sabbatical leave from Michigan State University, doing research for a study of twentieth century revolutions.

Professor Cumberland was born in Kingsville, Texas, in 1914. He received his A. B. (1936) and M. A. (1938) from Texas A. and I., taught high school briefly, and had started doctoral work at the University of Texas when World War II began. After service in the Pacific as a Navy lieutenant, he returned to Austin and took his $\mathrm{Ph}$. D. in 1949. His dissertation became his first book, Mexican Revolution: Genesis Under Madero (Austin, 1952). $\mathrm{He}$ taught at Princeton and Rutgers before going to Michigan State in 1955. There he remained, except for a year at the University of Madrid as a Fulbright Professor in 1961-1962.

In 1947 he married Emily McGee, who, with their daughter Jane, survives.

Charles Cumberland was one of the "second generation" of American scholars specializing in Latin American history. He studied under Charles Hackett, J. Lloyd Mecham, and Carlos Castañeda. From Hackett in particular, he acquired much of the sympathetic understanding of Mexico that characterizes all his writing on the subject. His lifelong second interest, the American West, was inspired by work with Walter Prescott Webb.

Although his research interests were wide, he made his most important contributions in the field of Mexican history. In addition to the Madero book, he published a socio-economic synthesis, Mexico: The Struggle for Modernity (New York, 1968) and edited a volume for the Heath series, The Meaning of the Mexican Revolution (New York, 1967). He devoted most of his last two years to writing a history of the Revolution from 1913 to 1920 . It will be published posthumously by the University of Texas Press under the title Mexican Revolution: The Constitutionalist Years. His many articles on Mexico include the pioneering monograph "Precursors of the Mexican Revolution of 1910" (HAHR, 1942), "An Analysis of the Program of the Mexican Liberal Party" (The Americas, 1948), "The Jenkins Case and Mexican-American Relations" (HAHR, 1951), "Genesis of Mexican Agrarian Reform" (The Historian, 1952), and "Constitutionalist Reaction to the Occupation of Veracruz" (Historia Mexicana, 1956).

Other publications include The United States-Mexican Border: A Selective Guide to the Literature of the Region (supplement to Rural Sociology, 1960), a study co-authored with Richard N. Adams, United States University Cooperation in Latin America (East Lansing, 1960), and various articles on Central American, Caribbean, and Texas history.

Cumberland was thorough, accurate, and comprehensive in his work. He 
cut through confusion and distortions to the core of a problem, pursued a point to its conclusion, and admitted it when he failed to find sure answers. Whether writing history, teaching a class, preparing a paper for a professional gathering, or reviewing a book, he insisted on the highest standardsand was always his own most severe critic.

Many who never met Charles Cumberland know and admire his scholarship. His friends, colleagues, and students remember the man as well. He was the soul of integrity, insisting always that intellectual honesty must guide human conduct. He condemned injustice, and had an unusual capacity to feel compassion for others. He was a gentle man who liked and trusted people, and his sense of personal dignity would never permit him to violate the dignity of another. He was utterly devoid of pompousness, and his quiet humor was most often directed at himself.

Charles Cumberland was a talented scholar and a complete human being. The profession will miss his scholarship; those who knew him will also miss the man.

North Carolina State University,

David C. Bailey Raleigh, Nortb Carolina

\section{Howard Francis Cline (1915-1971)}

H OWARD CLINE was stricken with a heart attack at his desk in the Library of Congress on June 8, 1971. His death removes from our scene the most active and best known Latin American historian of his generation.

Howard Cline's most celebrated book, The United States and Mexico, and its sequel, Mexico, Revolution to Evolution, are famous as informed expositions of Mexican history. The two books were designed as explanations of modern Mexico in historical terms, as works to be read by anyone interested in the subject. They represent summary popularization at its most effective. Their material is full, their organization clear, their tone that of informal communication. They provide basic historical information and interpretation, as well as the kinds of graphic, factual, and statistical detail that are most informative.

Persons familiar only with these two books have sometimes been surprised to discover that Howard Cline took additional delight in research scholarship of the most meticulous and demanding kind. This aspect of his work appeared principally in the form of journal articles, and most dealt with historical problems of colonial New Spain. A full study of the Mexican Indian calendar was nearly completed at his death. Those of us privileged to work with him on the ethnohistory volumes of the Handbook of Middle American Indians can appreciate further the painstaking labors he accom- 